\title{
Analisis Status Daya Dukung Air Di Sub DAS Cikeruh Menggunakan Metode Soil Conservation Curve Number (Scs-Cn)
}

\section{(The Analysis of Water Carrying Capacity Status in Cikeruh Sub-Watershed, using the Soil Conservation Service Curve Number (SCS-CN) Method)}

\author{
Kania Gita Pramadita*), Edy Suryadi, dan Dwi Rustam Kendarto \\ Program Studi Teknik Pertanian, Fakultas Teknologi Industri Pertanian Universitas Padjadjaran \\ *) kania16002@mail.unpad.ac.id
}

\begin{abstract}
The Cikeruh sub-watershed is an area with a high population growth rate, which causes land conversion to occur in several sub-districts hence has implications for decreasing water availability and increasing water demand in the Cikeruh sub-watershed. This study aims to determine the status of water carrying capacity in the Cikeruh sub-watershed by comparing the ratio between water demand and availability. Water demand is calculated using the standard determined by SNI 1966728.1, 2002; SNI 67281-2015; and the Directorate General of Human Settlements of the Public Works Service in 1996, while the sectors calculated are domestic, non-domestic, industrial, agriculture, animal husbandry, and fisheries. Water availability is calculated by estimating the volume of flow that occurs in the Cikeruh sub-watershed using the Soil Conservation Service Curve Number (SCS-CN) method from USDA involving hydrological data from 2011 to 2020. The result showed that the water availability in the Cikeruh sub-watershed in 2020 was $350,962,957.9 \mathrm{~m}^{3} /$ year, while the water demand in the Cikeruh sub-watershed changes dynamically every year. The water demand in the Cikeruh sub-watershed in 2011 was $588,925,151 \mathrm{~m}^{3} /$ year. In 2015, it was 754,796,534 $\mathrm{m}^{3} /$ year, while in 2020 was $571,509,488 \mathrm{~m}^{3} /$ year. The calculation results showed a water deficit in the Cikeruh sub-watershed, where the value of water demand is higher than the water availability, the ratio is 0.641 , which means that the environmental carrying capacity has exceeded (overshoot) because the ratio value is $<1$.
\end{abstract}

Keywords: Deficit, Environmental Carrying Capacity, Water Demand, Water Supply.

\begin{abstract}
ABSTRAK
Sub DAS Cikeruh merupakan kawasan dengan laju pertumbuhan penduduk yang tinggi, yang mana hal tersebut mengakibatkan alih fungsi lahan terjadi di beberapa kecamatan sehingga berimplikasi terhadap menurunnya ketersediaan air dan meningkatnya kebutuhan air di Sub DAS Cikeruh. Penelitian ini bertujuan untuk mengetahui status daya dukung air di Sub DAS Cikeruh melalui perbandingan rasio antara kebutuhan dan ketersediaan air. Kebutuhan air dihitung dengan menggunakan standar yang ditentukan oleh SNI 19-66728.1, 2002; SNI 67281-2015; dan Ditjen Cipta Karya Dinas PU tahun 1996, adapun sektor yang dihitung adalah domestik, non domestik, industri, pertanian, peternakan, dan perikanan. Ketersediaan air dihitung dengan mengestimasi volume aliran yang terjadi di Sub DAS Cikeruh menggunakan metode Soil Conservation Service Curve Number (SCS-CN) dari USDA dengan melibatkan data hidrologi dari tahun 2011 hingga 2020. Hasil penelitian menunjukkan bahwa ketersediaan air di Sub DAS Cikeruh pada tahun 2020 adalah sebesar 351.852.088,9 $\mathrm{m}^{3} /$ tahun, sedangkan kebutuhan air di Sub DAS Cikeruh mengalami perubahan yang dinamis setiap tahunnya. Kebutuhan air di Sub DAS Cikeruh pada tahun 2011 adalah sebesar 545.250.212 $\mathrm{m}^{3} /$ tahun, tahun 2015 sebesar $711.121 .596 \mathrm{~m}^{3} /$ tahun, sedangkan tahun 2020 sebesar 520.638.257 $\mathrm{m}^{3} /$ tahun. Hasil perhitungan menunjukkan bahwa terjadi defisit air di Sub DAS
\end{abstract}


Cikeruh, dimana nilai kebutuhan air lebih tinggi dibandingkan ketersediaan air, adapun rasionya sebesar 0,641, yang artinya daya dukung lingkungan telah terlampaui (overshoot) karena nilai rasio $<1$.

Kata Kunci: Daya Dukung Lingkungan, Defisit, Kebutuhan Air, Ketersediaan Air.

\section{PENDAHULUAN}

Pertumbuhan penduduk menjadi salah satu faktor penyebab alih fungsi lahan, karena pada dasarnya penggunaan lahan akan meningkat seiring dengan pertumbuhan penduduk yang meningkat pula. Alih fungsi lahan yang tidak memperhatikan faktor lingkungan dan bersifat mengubah bentang lahan pada suatu DAS seringkali akan mempengaruhi hasil air (Asdak, 2010). Meningkatnya jumlah penduduk akan memicu adanya aktivitasaktivitas baru yang akan berpengaruh pada pola penggunaan air yang tersedia, sehingga akan menimbulkan dampak negatif terhadap ketersediaan air. Kondisi tersebut akan memaksa suatu wilayah untuk dapat menjaga kualitas dan kuantitas sumber daya airnya, sehingga kebutuhan air dapat terpenuhi. Pengelolaan sumber daya air dapat dilakukan apabila status daya dukung air telah diketahui.

Sub DAS Cikeruh merupakan Sub DAS yang terletak di tiga wilayah administratif, yaitu Kabupaten Bandung, Kabupaten Sumedang dan Kota Bandung. Amaru et al (2013) menyatakan bahwa beberapa kecamatan di kawasan Sub DAS Cikeruh memiliki laju pertumbuhan penduduk yang tinggi di kabupaten masing-masing dan beberapa kecamatan lainnya merupakan pusatpusat perekonomian yang terus mengalami perkembangan dan akan berimplikasi pada tekanan yang semakin berat tehadap penggunaan lahan di Sub DAS Cikeruh. Oleh karena itu status daya dukung air di Sub DAS Cikeruh perlu diketahui karena akan menentukan faktor pembatas dalam pemanfaatan ruang yang sesuai, sehingga alih fungsi lahan dapat terkendali. Status daya dukung air dilakukan dengan membandingkan rasio antara kebutuhan dan ketersediaan air di suatu kawasan Sub DAS. Konsep perencanaan tata ruang berbasis daya dukung air merupakan jalan terwujudnya pengelolaan sumber daya air yang berkelanjutan.

\section{Tujuan Penelitian}

Tujuan dari penelitian ini adalah untuk mengetahui status daya dukung air di Sub DAS Cikeruh. Hasil penelitian diharapkan dapat dijadikan pertimbangan bagi pemerintah dalam menentukan gambaran tata ruang yang sesuai berdasarkan status daya dukung air di Sub DAS Cikeruh.

\section{METODOLOGI PENELITIAN}

\section{Alat}

Alat yang digunakan pada penelitian ini yaitu GPS (Global Positioning System) dan Laptop yang terdapat software Arcgis, Ms. Excel, Ms. Word didalamnya.

\section{Bahan}

Bahan yang digunakan pada penelitian ini yaitu data curah hujan tahunan dari tiga stasiun yang berada pada kawasan Sub DAS Cikeruh (Stasiun klimatologi Tanjungsari, SPMK Unpad, dan Rancaekek) dalam kurun waktu 10 tahun (2011-2020); Data jumlah penduduk di kawasan Sub DAS Cikeruh dalam kurun waktu 10 tahun; Data monografi kecamatan yang berada di kawasan Sub DAS Cikeruh dalam kurun waktu 10 tahun; Peta penggunaan lahan Provinsi Jawa Barat; Peta administrasi Provinsi Jawa Barat; Peta jenis tanah Provinsi Jawa Barat; Peta kemiringan lereng Provinsi Jawa Barat; Peta penggunaan lahan Provinsi Jawa Barat; dan Peta Sub DAS Cikeruh.

\section{Prosedur Penelitian}

Metode penelitian yang digunakan adalah analisis deskriptif melalui analisis variabel ketersediaan dan kebutuhan air.

\section{Ketersediaan Air}

Ketersediaan air dihitung dengan menggunakan metode SCS-CN yang 
dikembangkan oleh USDA. Metode SCS-CN dihitung dengan melibatkan data curah hujan di Sub DAS Cikeruh dari tahun 2011 hingga 2020, serta melibatkan kelompok hidrologi tanah, penggunaan lahan, tipe tutupan lahan, cara bercocok tanam, dan kondisi hidrologi di Sub DAS Cikeruh. Kondisi grup hidrologi tanah diperoleh berdasarkan hasil uji lab terkait tekstur tanah di Sub DAS Cikeruh. Berikut persamaan untuk memperoleh volume debit permukaan (USDA, 1988):

$$
\mathrm{Q}=\frac{(\mathrm{I}-0,2 \mathrm{~S})^{2}}{(\mathrm{I}-0,8 \mathrm{~S})}
$$

dimana:

$\mathrm{Q}=$ Debit permukaan $(\mathrm{mm})$

I $\quad=$ Curah hujan $(\mathrm{mm})$

$\mathrm{S}=$ Perbedaan antara curah hujan dan air larian $(\mathrm{mm})$ berikut:

Besarnya $S$ diperoleh dari persamaan

$$
\mathrm{S}=(25,400 / \mathrm{CN})-254
$$

Nilai CN bervariasi dari 1 hingga 100 tergantung pada pengggunaan lahan, kelompok hidrologi tanah, dan perlakuan yang diberikan. Sub DAS Cikeruh terdiri atas berbagai penggunaan lahan dan jenis tanah, sehingga nilai $\mathrm{CN}$ dihitung sebagai nilai komposit. Berikut persamaan untuk nilai $\mathrm{CN}$ komposit:

dimana:

$$
\mathrm{CN}_{\mathrm{kom}}=\frac{\sum \mathrm{Ai} \mathrm{x} \mathrm{CNi}}{\sum \mathrm{Ai}}
$$

$\mathrm{CN}_{\text {kom }}=\mathrm{CN}$ komposit

$\mathrm{A}_{\mathrm{i}} \quad$ = Luas setiap penggunaan lahan

$\mathrm{CN}_{\mathrm{i}}=\mathrm{CN}$ untuk setiap penggunaan lahan

Tabel 1. Kelompok hidrologi tanah berdasarkan tekstur tanah (Shaheed \& Almasri, 2010)

\begin{tabular}{cl}
\hline HSG & \multicolumn{1}{c}{ Tekstur Tanah } \\
\hline A & $\begin{array}{l}\text { Pasir, Pasir Berlempung, Lempung } \\
\text { Berpasir } \\
\text { Lempung, Debu, Lempung Berdebu, } \\
\text { B }\end{array}$ \\
Lempung Berpasir Sangat Halus \\
C & $\begin{array}{l}\text { Lempung Berliat, Lempung Liat } \\
\text { Berdebu, Lempung Liat Berpasir }\end{array}$ \\
D & Liat, Liat Berdebu, Liat Berpasir, Liat \\
\hline
\end{tabular}

Curah hujan rata-rata dihitung dengan menggunakan metode Polygon Thiessen. Metode ini cocok digunakan apabila pos hujan di suatu kawasan tidak banyak dan tinggi hujan tidak merata. Berikut persamaan yang digunakan:

$$
\bar{R}=\frac{A_{1} R_{1}+A_{2} R_{2}+A_{3} R_{3}+\ldots+A_{N} R_{N}}{A_{1}+A_{2}+A_{3}+\ldots+A_{N}}
$$

dimana:

$$
\begin{array}{ll}
\bar{R} & =\text { Hujan rata-rata }(\mathrm{mm}) \\
A_{1} & =\text { Luas masing-masing area (ha) } \\
R_{1} & =\text { Curah hujan masing-masing stasiun } \\
& (\mathrm{mm})
\end{array}
$$

\section{Kebutuhan Air}

Penelitian berlokasi di Sub DAS Cikeruh, sehingga secara geografis, lokasi yang digunakan untuk menghitung kebutuhan air hanya sebatas pada kecamatan dan desa yang ada di Sub DAS Cikeruh. Secara administratif Sub DAS Cikeruh berada pada 12 kecamatan yang terletak di Kabupaten Bandung, Kabupaten Sumedang, dan Kota Bandung. Dua belas kecamatan yang masuk ke dalam Sub DAS Cikeruh diantaranya Kecamatan Bojongsoang, Kecamatan Cilengkrang, Kecamatan Cimenyan, Kecamatan Cileunyi, Kecamatan Rancaekek, Kecamatan Cibiru, Kecamatan Rancasari, Kecamatan Ujungberung, Kecamatan Cimanggung, Kecamatan Jatinangor, Kecamatan Sukasari, dan Kecamatan Tanjungsari.

Kebutuhan air dibagi ke dalam enam sektor yaitu domestik, non domestik, industri, pertanian, perikanan, dan peternakan. Sektor domestik, perikanan dan perternakan dihitung dengan menggunakan acuan SNI 6728.1 2015, kebutuhan air industri ditentukan berdasarkan jenis industri yang ada pada kawasan penelitian, kebutuhan air pertanian merujuk pada Surat Edaran Menteri PUPR Nomor 07 Tahun 2018, sedangkan kebutuhan air non domestik merujuk pada hasil penelitian-penelitian sebelumnya yang terkait.

Kebutuhan air domestik yang dimaksud pada penelitian ini adalah kebutuhan air bersih untuk kebutuhan rumah tangga, dihitung dengan persamaan sebagai berikut:

$$
\mathrm{Q}_{\text {dom }}=365 \text { hari } \times\left\{\frac{\mathrm{q}}{1000} \times \mathrm{P}\right\}
$$

dimana Qdom adalah konsumsi air sektor domestik ( $\mathrm{m}^{3} /$ tahun), q adalah konsumsi air berdasarkan kategori kota (liter/kapita/hari), dan $\mathrm{P}$ adalah jumlah penduduk. 
Tabel 2. Standar kebutuhan air menurut kategori kota

\begin{tabular}{lcc}
\hline Kategori Kota & $\begin{array}{c}\text { Jumlah } \\
\text { Penduduk } \\
\text { (Jiwa) }\end{array}$ & $\begin{array}{c}\text { Kebutuhan } \\
\text { Air Bersih } \\
\text { (L/O/H) }\end{array}$ \\
\hline Semi urban (ibu & $3.000-$ & \\
kota & 20.000 & $60-90$ \\
kecamatan/desa) & $20.000-$ & \\
Kota kecil & 100.000 & $90-110$ \\
& $100.000-$ & $100-125$ \\
Kota sedang & 500.000 & \\
& $500.000-$ & $120-150$ \\
Kota besar & 1.000 .000 & $150-200$ \\
& $>1.000 .000$ & \\
Metropolitan & &
\end{tabular}

Sumber: SNI 67281-2015

Kebutuhan air non domestik dibagi ke dalam tujuh fasilitas yaitu fasilitas rumah ibadah, pendidikan, kesehatan, niaga, pariwisata, lembaga keuangan, kost-kostan.

Tabel 3. Standar untuk fasilitas perkotaan (Ditjen Cipta Karya Dinas PU, 1996)

\begin{tabular}{lc}
\hline Fasilitas Perkotaan & $\begin{array}{c}\text { Standar Kebutuhan } \\
\text { Air }\end{array}$ \\
\hline Masjid & $2\left(\mathrm{~m}^{3} /\right.$ hari/unit $)$ \\
Langgar & $2\left(\mathrm{~m}^{3} /\right.$ hari/unit $)$ \\
Gereja & $2\left(\mathrm{~m}^{3} /\right.$ hari/unit $)$ \\
Pura & $2\left(\mathrm{~m}^{3} /\right.$ hari/unit $)$ \\
Vihara & $2\left(\mathrm{~m}^{3} /\right.$ hari/unit $)$ \\
Sekolah (SD, SMP, & $15(1 /$ siswa/hari $)$ \\
SMA/K) & $20(1 /$ siswa/hari $)$ \\
Perguruan Tinggi & $400(1 /$ tempat \\
Rumah Sakit & tidur/hari $)$ \\
& $2\left(\mathrm{~m}^{3} /\right.$ hari/unit $)$ \\
Puskesmas $\quad$ Toko, & $900(1 /$ unit/hari $)$ \\
Minimarket, & $5000(1 /$ unit/hari $)$ \\
Tostoran, Kedai & $400(1 /$ kamar/hari $)$ \\
Hotel Mall & $5700(1 /$ unit/hari $)$ \\
Bank, Lembaga & $115(1 /$ orang/hari $)$ \\
Keuangan &
\end{tabular}

Persamaan untuk menghitung kebutuhan air fasilitas rumah ibadah adalah sebagai berikut:

$\begin{array}{ll}\text { Qib(mas) } & =\sum \text { masjid } \times 365 \text { hari } \times \text { q(ibmas) } \\ \text { Qib(mus) } & =\sum \text { mushola } \times 365 \text { hari } \times \\ & \text { q(ibmus) } \\ \text { Qib(grj) } & =\sum \text { gereja } \times 365 \text { hari } \times \text { q(ibgrj) } \\ \text { Qib(pura) } & =\sum \text { pura } \times 365 \text { hari } \times \text { q(ibpura) } \\ \text { Qib(vhr) } & \left.=\sum \text { vihara } \times 365 \text { hari } \times \text { q(ibvhr }\right)\end{array}$

Qib

$$
\begin{aligned}
& =\text { Qib(mas) + Qib(mus) }+ \\
& \text { Qib(grj) + Qib(pura) }+ \\
& \text { Qib(vhr) }
\end{aligned}
$$

dimana Qib adalah konsumsi air sektor non domestik ( $\mathrm{m}^{3} /$ tahun), Qib(mas) adalah konsumsi air masjid, Qib(mus) adalah konsumsi air mushola, Qib(grj) konsumsi air gereja, Qib(pura) adalah konsumsi air pura, Qib(vhr) adalah konsumsi air vihara, q(ibmas) adalah standar konsumsi air masjid, q(ibmus) adalah standar konsumsi air mushola, q(ibgrj) adalah standar konsumsi air gereja, q(ibpura) adalah standar konsumsi air pura, dan sttandar konsumsi air vihara.

Persamaan untuk menghitung kebutuhan air fasilitas pendidikan adalah sebagai berikut: $\mathrm{Qp}($ sekolah $)=\sum$ murid $\mathrm{x} \frac{\mathrm{q} \text { (psekolah) }}{1000} \times 365$ hari Qp (PT) $\quad=$ Emahasiswa $\times \frac{\mathrm{q}(\mathrm{pPT})}{1000} \times 365$ hari

Qp $\quad=\mathrm{Qp}($ sekolah $)+\mathrm{Qp}(\mathrm{PT})$

dimana Qp adalah konsumsi air untuk fasilitas pendidikan ( $\mathrm{m}^{3} /$ tahun), Qp(sekolah) adalah konsumsi air untuk fasilitas sekolah (SD, SMP, SMA/K), Qp(PT) adalah konsumsi air untuk fasilitas perguruan tinggi, $\mathrm{q}($ psekolah) adalah standar konsumsi air per murid, dan q(pPT) adalah standar konsumsi air per mahasiswa.

Persamaan untuk menghitung kebutuhan air fasilitas kesehatan adalah sebagai berikut: Qs (puskesmas) $=\sum$ unit $\times 365$ hari $\times$ q(sp)

Qs (rumah sakit) $=\sum$ bed $\times 365$ hari $\times \frac{\mathrm{q}(\mathrm{srs})}{1000}$ Qs

$$
\begin{aligned}
& =\mathrm{Qs} \text { (puskesmas) }+\mathrm{Qs} \\
& \text { (rumah sakit) }
\end{aligned}
$$

dimana Qs adalah konsumsi air untuk fasilitas kesehatan ( $\mathrm{m}^{3} /$ tahun), Qs (puskesmas) adalah konsumsi air untuk fasilitas puskesmas, Qs (rumah sakit) adalah konsumsi air untuk fasilitas rumah sakit, $\mathrm{q}(\mathrm{sp})$ adalah konsumsi air per unit puskesmas, dan $\mathrm{q}(\mathrm{srs})$ adalah konsumsi air per unit rumah sakit

Persamaan untuk menghitung kebutuhan air fasilitas niaga adalah sebagai berikut:

$\mathrm{Qn}(\mathrm{mm})=\sum$ minimarket $\mathrm{x} 365$ hari $\mathrm{x}$

$$
\frac{\sum_{(\mathrm{nmm})}}{1000}
$$

Qn(toko) $=\sum$ toko $x 365$ hari $\mathrm{x} \frac{\mathrm{q} \text { (ntoko) }}{1000}$

Qn(resto) $\quad=\sum$ restoran $\times 365$ hari $\mathrm{x} \frac{\mathrm{q} \text { (nresto) }}{1000}$

Qn(toserba) $=\sum$ toserba $\times 365$ hari $\mathrm{x}$

$$
\frac{\mathrm{q}(\text { ntoserba) }}{1000}
$$




$\begin{array}{ll}\text { Qn (mall) } & =\sum \text { mall x } 365 \text { hari x } \frac{\mathrm{q}(\text { mall })}{1000} \\ \text { Qn (kedai) } & =\sum \text { kedai x } 365 \text { hari x } \frac{\mathrm{q} \text { (nkedai) }}{1000} \\ \text { Qn } & =\text { Qn }(\mathrm{mm})+\text { Qn (toko) }+ \\ & \text { Qn }(\text { resto })+\text { Qn }(\text { toserba })+ \\ & \text { Qn }(\text { mall })+\text { Qn }(\text { kedai })\end{array}$

dimana Qn adalah konsumsi air untuk fasilitas niaga ( $\mathrm{m}^{3} /$ tahun), Qn(mm) adalah konsumsi air mini market, Qn(toko) adalah konsumsi air toko, Qn(resto) adalah konsumsi air untuk restoran, Qn(toserba) adalah konsumsi air untuk toserba, Qn(mall) adalah konsumsi air untuk mall, Qn(kedai) adalah konsumsi air untuk kedai, $\mathrm{q}(\mathrm{nmm})$ adalah standar konsumsi air mini market, $\mathrm{q}$ (ntoko) adalah standar konsumsi air toko, q(nresto) adalah standar konsumsi air restoran, qn(toserba) adalah standar konsumsi air toserba, qn(mall) adalah standar konsumsi air mall, dan qn(kedai) adalah standar konsumsi air kedai.

Persamaan untuk menghitung kebutuhan air fasilitas pariwisata (hotel) dan lembaga keuangan adalah sebagai berikut:

$\mathrm{Q}($ hotel $)=365 \times \sum \operatorname{kamar} \times \frac{\mathrm{q}(\text { hotel })}{1000}$

$\mathrm{Q}(\mathrm{LK})=365 \times \sum$ lembagakeuangan $\mathrm{x} \frac{\mathrm{q}(\mathrm{LK})}{1000}$

dimana $\mathrm{Q}$ (hotel) adalah konsumsi air untuk fasilitas perhotelan ( $\mathrm{m}^{3} /$ tahun), $\mathrm{q}$ (hotel) adalah standar konsumsi air perhotelan, Q(LK) adalah konsumsi air untuk fasilitas lembaga keuangan ( $\mathrm{m}^{3} /$ tahun), dan $\mathrm{q}(\mathrm{LK})$ adalah standar konsumsi air lembaga keuangan.

Kebutuhan kost-kostan dihitung berdasarkan jumlah mahasiswa yang tinggal di Kawasan Pendidikan Tinggi di Kecamatan Jatinangor. Persamaan yang digunakan untuk menghitung kebutuhan air kost-kostan adalah sebagai berikut:

$\mathrm{Qk}=\sum$ mahasiswa $\mathrm{x} 365$ hari $\mathrm{x} \frac{\mathrm{q}(\mathrm{k})}{1000}$

dimana Qk adalah konsumsi air untuk fasilitas kost-kostan $\mathrm{m}^{3} /$ tahun), dan $\mathrm{q}(\mathrm{k})$ adalah standar konsumsi air kost-kostan.

Kebutuhan air irigasi diperuntukkan untuk tanaman padi dan palawija. Merujuk pada Surat Edaran Menteri Pekerjaan Umum dan Perumahan Rakyat tentang Pedoman Pembangunan Embung Kecil dan Bangunan Penampung Air Lainnya di Desa Tahun 2018, disebutkan bahwa standar kebutuhan air untuk irigasi tanaman padi adalah sebesar 1 liter/detik/hektar, sedangkan kebutuhan air irigasi untuk tanaman palawija adalah sebesar 0,8 liter/detik/hektar. Persamaan yang digunakan untuk menghitung kebutuhan air pertanian pada penelitian ini adalah sebagai berikut (SNI 19-66728.1, 2002) :

$$
\mathrm{Q}_{\mathrm{IR}}=\mathrm{L} \times \text { It } \mathrm{x} \text { a }
$$

dimana:

$$
\begin{array}{ll}
\mathrm{Q}_{\text {IR }} & =\text { Kebutuhan air irigasi }\left(\mathrm{m}^{3} / \text { tahun }\right) \\
\mathrm{L} & =\text { Luas sawah }(\mathrm{ha}) \\
\mathrm{It} & =\text { Intensitas penanaman } \\
\mathrm{a} & =\text { Standar penggunaan irigasi }
\end{array}
$$

Kebutuhan air untuk sektor peternakan dihitung berdasarkan jumlah jenis ternak yang ada di Sub DAS Cikeruh. Persamaan yang digunakan sebagai berikut:

$$
\mathrm{Q}_{\mathrm{E}}=\left(\mathrm{q}_{(1)} \times \mathrm{P}_{(1)}+\mathrm{q}_{(2)} \times \mathrm{P}_{(2)}+\mathrm{q}_{(3)} \times \mathrm{P}_{(3)}\right)
$$
dimana:

$\mathrm{Q}_{\mathrm{E}}=$ kebutuhan air untuk sektor peternakan (liter/hari)

$\mathrm{q}_{(1)}=$ kebutuhan air untuk sapi, kerbau, dan kuda (liter/ekor/hari)

$\mathrm{q}_{(2)}=$ kebutuhan air untuk kambing dan domba (liter/ekor/hari)

$\mathrm{q}_{(3)}=$ kebutuhan air untuk unggas (liter/ekor/hari)

$\mathrm{P}_{(1)} \quad=$ jumlah sapi, kerbau, dan kuda (ekor)

$\mathrm{P}_{(2)} \quad=$ jumlah kambing dan domba (ekor)

$\mathrm{P}_{(3)} \quad=$ jumlah unggas (ekor)

Tabel 4. Kebutuhan air untuk ternak

\begin{tabular}{cc}
\hline Jenis Ternak & $\begin{array}{c}\text { Kebutuhan Air } \\
\text { (liter/ekor/hari) }\end{array}$ \\
\hline Sapi/kerbau/kuda & 40 \\
Kambing/domba & 5 \\
Babi & 6 \\
Unggas & 0,6 \\
\hline
\end{tabular}

Kebutuhan air untuk perikanan meliputi kebutuhan air untuk mengisi kolam pada saat awal tanam dan penggantian air, berikut persamaannya:

$$
\text { Qfp }=\frac{q(f p)}{1000} \times A(f p) \times 10000
$$

dimana:

Qfp = kebutuhan air untuk sektor perikanan $\left(\mathrm{m}^{3} /\right.$ hari $)$

$\mathrm{q}(\mathrm{fp})=$ kebutuhan air untuk pembilasan (1/hari/ha)

$\mathrm{A}(\mathrm{fp})=$ luas kolam ikan (ha)

Kebutuhan air industri dihitung berdasarkan jumlah jenis industri yang ada di Sub DAS Cikeruh, berikut persamaannya:

$$
\mathrm{Q} \text { (ind) } \mathrm{i}=\mathrm{N}(\text { ind }) \times \mathrm{q} \text { (ind) } \times \mathrm{n}
$$


dimana:

$$
\begin{aligned}
& \mathrm{Q} \text { (ind) }=\text { Kebutuhan air industri }\left(\mathrm{m}^{3}\right) \text { pada } \\
& \text { bulan ke-i } \\
& \mathrm{N}(\text { ind })=\text { Jumlah industri (unit) } \\
& \mathrm{q} \text { (ind) }=\text { Konsumsi air setiap jenis industri } \\
& \text { (besar, sedang, atau kecil) } \\
& \text { ( } \mathrm{m}^{3} / \text { unit/hari) } \\
& \mathrm{n} \quad=\text { jumlah hari pada bulan ke } \mathrm{i}
\end{aligned}
$$

\section{Status Daya Dukung Air}

Penentuan status daya dukung lingkungan berdasarkan rasio dapat ditentukan setelah diketahui besarnya ketersedian air dan kebutuhan air pada lokasi studi.

Tabel 5. Kriteria penetapan status DDL air

\begin{tabular}{ll}
\hline \multicolumn{1}{c}{ Kriteria } & \multicolumn{1}{c}{ Status DDL air } \\
\hline $\begin{array}{l}\text { Rasio Supply/demand }> \\
2\end{array}$ & $\begin{array}{l}\text { Daya dukung } \\
\text { lingkungan aman } \\
\text { (sustain) }\end{array}$ \\
Rasio Supply/demand 1 & $\begin{array}{l}\text { Daya dukung } \\
\text { lingkungan aman } \\
-2\end{array}$ \\
bersyarat \\
(conditional sustain) \\
Rasio Supply/demand $<$ \\
1
\end{tabular}

(Sumber: Peraturan Menteri Negara Lingkungan Hidup Nomor 17 Tahun 2009)

Bila $S A>D A$, daya dukung air dinyatakan surplus. Bila $S A<D A$, daya dukung air dinyatakan defisit atau terlampaui.

\section{HASIL DAN PEMBAHASAN}

Sub DAS Cikeruh memiliki luas sebesar 19.143,21 ha. Berdasarkan peta penggunaan lahan, diketahui bahwa Sub DAS Cikeruh memiliki 12 (dua belas) jenis penggunaan lahan, yang meliputi sawah tadah hujan, sawah, tanah kosong/gundul, ladang, kebun, pemukiman, bangunan, danau, hutan, semak belukar, tanaman legum, dan sungai. Penggunaan lahan didominasi oleh pemukiman dengan persentase sebesar $29,44 \%$, sedangkan penggunaan lahan yang memiliki luas terkecil adalah sungai dengan persentase sebesar $0,03 \%$ dan diikuti dengan tanaman legum dengan persentase sebesar $0,04 \%$.

Sub DAS Cikeruh memiliki 4 (empat) jenis tanah, yaitu kambisol, gleisol, latosol, dan andosol. Berdasarkan hasil uji lab yang dilakukan dari mentumpang tindih peta jenis tanah dan penggunaan lahan, diketahui bahwa Sub DAS Cikeruh memiliki tekstur tanah liat dan liat berdebu. Oleh sebab itu Sub DAS Cikeruh masuk ke dalam kategori D pada

\begin{tabular}{|c|c|c|c|c|c|c|}
\hline Tipe Tutupan Lahan & $\begin{array}{c}\text { Kelas } \\
\text { Hidrologi }\end{array}$ & $\begin{array}{l}\text { Keadaan } \\
\text { Hidrologi }\end{array}$ & Luas (Ha) & $\begin{array}{c}\text { Luas } \\
(\%)\end{array}$ & $\begin{array}{c}\text { Angka } \\
\text { CN }\end{array}$ & $\begin{array}{c}\text { CN } \\
\text { Tertimbang }\end{array}$ \\
\hline Danau/Situ & D & & 15,21 & 0,08 & 100 & 1521 \\
\hline Gedung/Bangunan & $\mathrm{D}$ & & 450,74 & 2,35 & 98 & 44172,52 \\
\hline Hutan & $\mathrm{D}$ & Baik & 1250,25 & 6,53 & 77 & 96269,25 \\
\hline Perkebunan/Kebun & $\mathrm{D}$ & Baik & 3458,40 & 18,07 & 77 & 266296,8 \\
\hline $\begin{array}{c}\text { Pemukiman/Tempat } \\
\text { Kegiatan }\end{array}$ & $\mathrm{D}$ & & 5635,84 & 29,44 & 92 & 518497,28 \\
\hline Sawah & $\mathrm{D}$ & Buruk & 3898,28 & 20,36 & 88 & 343048,64 \\
\hline Sawah Tadah Hujan & $\mathrm{D}$ & Buruk & 753,00 & 3,93 & 86 & 64758 \\
\hline Semak Belukar & $\mathrm{D}$ & Sedang & 296,49 & 1,55 & 89 & 26387,61 \\
\hline Sungai & $\mathrm{D}$ & & 5,71 & 0,03 & 100 & 571 \\
\hline $\begin{array}{c}\text { Tanah } \\
\text { Kosong/Gundul }\end{array}$ & $\mathrm{D}$ & & 555,38 & 2,90 & 93 & 51650,34 \\
\hline Tegalan/Ladang & $\mathrm{D}$ & Baik & 2816,58 & 14,71 & 89 & 250675,62 \\
\hline $\begin{array}{l}\text { Vegetasi non } \\
\text { budidaya }\end{array}$ & $\mathrm{D}$ & Baik & 7,33 & 0,04 & 80 & 586,4 \\
\hline Total & \multirow{2}{*}{\multicolumn{6}{|c|}{$\frac{19143,21 \quad 100,00}{\mathbf{8 6 , 9 4}}$}} \\
\hline CN Komposit & & & & & & \\
\hline
\end{tabular}
kelompok hidrologi tanah. Kategori D memiliki potensi air larian tinggi, kebanyakan tanah liat, dangkal dengan lapisan kedap air dekat permukaan tanah dengan laju infiltrasi yang sangat rendah.

Tabel 6. Penetapan Nilai CN 
CN menggambarkan hubungan antara volume limpasan dengan sifat DAS, dimana semakin besar nilai CN maka semakin kecil air yang terinfiltrasi, dan semakin besar debit permukaannya. Ketersediaan air dihitung dengan melibatkan nilai curah hujan rata-rata di Sub DAS Cikeruh selama 10 tahun terakhir, adapun nilai rata-ratanya adalah sebesar 1883 $\mathrm{mm} /$ tahun. Kelembaban tanah awal yang digunakan adalah AMC II atau kondisi normal, sehingga total ketersediaan air Sub DAS Cikeruh adalah sebesar $351.852 .088,7 \mathrm{~m}^{3}$.

Kebutuhan air dihitung selama 10 tahun terakhir yaitu dari tahun 2011 hingga 2020 di 12 kecamatan yang ada di kawasan Sub DAS Cikeruh. Kebutuhan air sektor domestik dihitung dengan menggunakan standar kebutuhan kota besar, karena jumlah penduduk Sub DAS Cikeruh berada pada rentang 500.000 - 1.000.000. Jumlah penduduk di Sub DAS Cikeruh meningkat setiap tahunnya, sehingga kebutuhan airnya pun turut bertambah.

Kebutuhan air non domestik menunjukkan nilai yang dinamis setiap tahunnya. Beberapa fasilitas menggunakan asumsi dalam perhitungannya, seperti jumlah tempat tidur di rumah sakit, hal tersebut dikarenakan terdapat keterbatasan dari data yang diperoleh, adapun asumsinya merujuk pada Komisi Akreditasi Rumah Sakit. Fasilitas hotel pun menggunakan asumsi pada jumlah kamar tidurnya, dimana berdasarkan hasil survey diketahui bahwa hotel yang ada di Sub DAS Cikeruh merupakan hotel bintang tiga sehingga diasumsikan setiap hotel memiliki jumlah kamar tidur sebanyak 32 buah. Adapun asumsinya merujuk pada Peraturan Menteri Pariwisata dan Ekonomi Kreatif tentang Standar Usaha Hotel. Kebutuhan air untuk kost-kostan dihitung karena Kecamatan Jatinangor merupakan Kawasan Pendidikan Tinggi (KPT), yang mana didalamnya terdapat 5 perguruan tinggi yaitu Universitas Padjadjaran, Institut Teknologi Bandung, IPDN (Institut Pemerintahan Dalam Negeri), dan IKOPIN (Institut Koperasi Indonesia).

Pola tanam untuk menghitung kebutuhan air irigasi diketahui berdasarkan hasil wawancara dengan staf kecamatan di Sub DAS Cikeruh. Pola tanam yang digunakan adalah padi-padi-bera untuk sawah irigasi dengan intensitas tanam sebanyak 2 musim/tahun, dan padi-palawija-bera untuk sawah tadah hujan dengan intensitas tanam sebanyak 1 musim/tahun untuk tanaman padi dan 2 musim/tahun untuk tanaman palawija. Kebutuhan air irigasi dihitung dengan menggunakan luas sawah yang ada di Sub DAS Cikeruh. Kebutuhan air perikanan menggunakan standar untuk pembilasan yaitu sebesar $7 \mathrm{~mm} /$ hari/hektar.

Kebutuhan air untuk sektor pertanian dan perikanan diasumsikan sama dari tahun 2011 hingga 2020, hal tersebut dikarenakan terdapat keterbatasan dalam memperoleh data penggunaan lahan, sehingga luas penggunaan lahan yang digunakan adalah penggunaan lahan terbaru yaitu tahun 2020. Kebutuhan air untuk peternakan cenderung menurun setiap tahunnya, karena jumlah ternak cenderung akan menurun apabila alih fungsi lahan terus terjadi. Kebutuhan air industri merupakan kebutuhan air yang paling besar dibandingkan kebutuhan air lainnya. Menurut Resubun (2019), standar kebutuhan air untuk sektor industri berdasarkan klasifikasinya adalah $3.805 .200 \mathrm{~m}^{3} /$ tahun untuk industri besar, $1.064 .880 \mathrm{~m}^{3} /$ tahun untuk industri sedang, dan $20.400 \mathrm{~m}^{3} /$ tahun untuk industri kecil.

Tabel. Kebutuhan Air Sub DAS Cikeruh

\begin{tabular}{ccccccccc}
\hline \multirow{2}{*}{ No } & \multirow{2}{*}{ Tahun } & \multicolumn{7}{c}{ Kebutuhan Air $\left(\mathbf{m}^{\mathbf{3} / \text { tahun })}\right.$} \\
\cline { 3 - 9 } & & Domestik & Non Domestik & Industri & Perikanan & Peternakan & Pertanian & TOTAL \\
\hline 1 & 2011 & 47.799 .707 & 11.528 .953 & 388.512 .720 & 388.697 & 227.356 & 96.792 .780 & 545.250 .212 \\
2 & 2012 & 48.551 .035 & 15.886 .175 & 508.659 .840 & 389.762 & 279.411 & 96.792 .780 & 670.559 .002 \\
3 & 2013 & 48.247 .288 & 9.139 .882 & 547.327 .440 & 388.697 & 322.874 & 96.792 .780 & 702.218 .961 \\
4 & 2014 & 49.024 .957 & 10.903 .048 & 545.197 .680 & 388.697 & 156.870 & 96.792 .780 & 702.464 .031 \\
5 & 2015 & 50.756 .152 & 11.880 .959 & 551.132 .640 & 388.697 & 170.368 & 96.792 .780 & 711.121 .596 \\
6 & 2016 & 51.741 .768 & 13.253 .043 & 448.562 .880 & 389.762 & 451.841 & 96.792 .780 & 611.192 .073 \\
7 & 2017 & 51.434 .121 & 21.928 .280 & 455.718 .960 & 388.697 & 164.741 & 96.792 .780 & 626.427 .578 \\
8 & 2018 & 52.604 .129 & 20.500 .347 & 532.575 .360 & 388.697 & 123.155 & 96.792 .780 & 702.984 .467
\end{tabular}




\begin{tabular}{ccccccccc}
\hline \multirow{2}{*}{ No } & \multirow{2}{*}{ Tahun } & \multicolumn{7}{c}{ Kebutuhan Air $\left(\mathbf{m}^{\mathbf{3}} / \mathbf{t a h u n}\right)$} \\
\cline { 3 - 8 } & & Domestik & Non Domestik & Industri & Perikanan & Peternakan & Pertanian & TOTAL \\
\hline 9 & 2019 & 53.028 .386 & 24.713 .631 & 551.743 .200 & 388.697 & 158.220 & 96.792 .780 & 726.824 .914 \\
10 & 2020 & 46.577 .215 & 9.857 .048 & 366.862 .800 & 389.762 & 158.653 & 96.792 .780 & 520.638 .257 \\
\hline
\end{tabular}

Analisis status daya dukung lingkungan dengan pendekatan air (status daya dukung air) merupakan rasio antara kondisi ketersediaan air dengan kebutuhan air yang ada di suatu Sub DAS. Semakin tinggi nilai ketersediaan air maka nilai rasio akan semakin besar, yang mana menunjukan bahwa status daya dukung air surplus yaitu terjaminnya kondisi ketersediaan air untuk memenuhi kebutuhan air masyarakat. Sebaliknya, semakin rendah nilai ketersediaan air maka nilai rasio akan semakin kecil, yang mana menunjukkan bahwa status daya dukung air defisit yaitu tidak terjaminnya kondisi ketersediaan air untuk memenuhi kebutuhan air masyarakat.

Berdasarkan perhitungan, nilai ketersediaan air di Sub DAS Cikeruh adalah sebesar 351.852.088,7 $\mathrm{m}^{3}$, sedangkan total nilai kebutuhan airnya sebesar $520.638 .257 \mathrm{~m}^{3}$. Nilai ketersediaan air di Sub DAS Cikeruh lebih kecil dibandingkan nilai kebutuhan airnya, sehingga daya dukung air dinyatakan defisit. Adapun apabila nilai ketersediaan air yang diperoleh diasumsikan tetap dari tahun 2011 hingga 2020, maka kondisi defisit sudah terjadi dari tahun 2011.

Masalah defisit di Sub DAS Cikeruh menunjukkan bahwa daya dukung lingkungan telah terlampaui, sehingga perlu penyelesaian agar permasalahan defisit air dapat teratasi. Berdasarkan hasil wawancara, permasalahan banjir pada musim hujan dan kekeringan di Sub DAS Cikeruh diakibatkan oleh kawasan hulu Sub DAS Cikeruh yang terganggu, daerah hulu yang semestinya menjadi daerah resapan, dialihfungsikan menjadi kawasan pemukiman, hal tersebutlah yang menyebabkan pengelolaan sumber daya air terganggu.

\section{KESIMPULAN}

Status daya dukung air di Sub DAS Cikeruh termasuk ke dalam kondisi terlampaui (overshoot), dengan nilai rasio sebesar 0,675 sehingga ketersediaan air di Sub DAS Cikeruh tidak bisa memenuhi permintaan kebutuhan air masyarakat.

\section{DAFTAR PUSTAKA}

Amaru, K., NP, Sophia. D., Bafdal, N., \& Abidin, J. (2013). Penentuan Tingkat Bahaya Erosi dengan Menggunakan Sistem Informasi Geografis di Sub DAS Cikeruh Kabupaten Bandung-Sumedang. Teknotan: Jurnal Industri Teknologi Pertanian, 7(3).

Asdak, C. (2010). Hidrologi dan Pengelolaan Daerah Aliran Sungai. Yogyakarta: Gadjah Mada University Press.

Badan Pusat Statistik Provinsi Jawa Barat. (2019). Jawa Barat Dalam Angka 2019. BPS Provinsi Jawa Barat.

Badan Standardisasi Nasional. (2015). SNI 6728.1-2015 Penyusunan Neraca Spasial Sumber Daya Alam Bagian I: Sumber Daya Air.

Ditjen Cipta Karya, Departemen Pekerjaan Umum. (1990). Analisis Kebutuhan Air Bersih. Jakarta.

Kementerian Pekerjaan Umum dan Perumahan Rakyat. (2018). Pedoman Pembangunan Embung Kecil dan Bangunan Penampung Air Lainnya di Desa. Surat Edaran Nomor: 07/SE/M/2018.

Peraturan Menteri Negara Lingkungan Hidup Nomor 17 tahun 2009 Tentang Pedoman Penentuan Daya Dukung Lingkungan Hidup dalam Penataan Ruang Wilayah.

Republik Indonesia. (2019). Undang-Undang No 17 Tahun 2019 Tentang Sumber Daya Air. Lembaran Negara RI Tahun 2019. Sekretariat Negara. Jakarta.

Resubun, M. L., Wahjunie, E. D., \& Tarigan, S. D. (2019). Analisis Ketersediaan Dan Kebutuhan Air di DAS Cisangkuy. Musamus AE Featuring Journal (MAEFJ), 2(1), 1-10. 